\title{
Pemanfaatan Intensitas Radiasi Cahaya Lampu dengan Reflektor Panel Surya sebagai Energi Harvesting
}

\author{
Haris Romadhon ${ }^{1}$, Budiyanto ${ }^{2}$ \\ 1) 2) Teknik Elektro Universitas Muhammadiyah Jakarta \\ Jl. Cempaka Putih Tengah 27 \\ Email: ${ }^{1)}$ 2013420009@ftumj.ac.id , 2) yan.budiyanto@yahoo.com
}

\begin{abstract}
ABSTRAK
Energy Harvesting dapat dimanfaatkan sebagai energi alternatif baru terbarukan yang dapat memanen energi listrik yang terbuang, Pemanfaatan energi ini untuk pemanfaatan lampu emergency yang digunakan pada saat sumber utama mati.Pemanenan energy ini dimanfaatkan untuk lampu yang menyala lebih dari 18 jam oleh karna itu pemakian yang lama dapat mengahsilkan energy baru. Penggunaan lampu lampu dengan intensitas tinggi yang dapat dimaksimalkan untuk pemanfaatan panel surya karna penel surya terkena sinar lebih banyak.Penelitian ini diharapkan menjadi sumber listrik alternative baru terbarukan dimasa mendatang. Sumber energy harvesting ini agar biasa dimanfaatan dan dapat dikelola dengan baik sehingga dapat memenuhi kebutuhan energi pada masa yang akan datang.Hal ini melandasi penulis untung merancang serta membuat suata alat yang dapat digunakan untuk pemanenan energi dengan menganalisa alat yang dirancang semaksimal mungkin yaitu "Pemanfaatan Intensitas Radiasi Cahaya Lampu Dengan Reflektor Panel Surya Sebagai Energy Harvesting “. Dari penelitian ini diharapkan dapat memberikan suatu sumber energi baru yang dapat dimanfaatkan dari panel surya dengan menggunakan cahaya lampu.
\end{abstract}

kata kunci: energy harvesting, panel surya, lampu, cahaya

\begin{abstract}
Energy Harvesting can be used as a new alternative renewable energy that can harvest wasted electrical energy. Utilization of this energy for the utilization of emergency lights that are used when the main source dies. Harvesting this energy is used for lights that burn more than 18 hours because of that long usage can produce new energy. The use of lamps with high intensity that can be maximized for the utilization of solar panels because solar cells are exposed to more light. This research is expected to be a new alternative renewable electricity source in the future. This source of energy harvesting should be used and managed properly so that it can meet energy needs in the future. This is the basis for the author to design and create a tool that can be used for harvesting energy by analyzing the tools designed as fully as possible, namely "Intensity Utilization Light Radiation Lamps With Solar Panel Reflectors As Energy Harvesting ". From this research it is expected to provide a new energy source that can be utilized from solar panels by using light bulbs.
\end{abstract}

keywords: energy harvesting, solar panels, lamps, light

\section{PENDAHULUAN}

Pada era modern saat ini banyak gedunggedung bertingkat dan gedung manufacturing yang dimana terbatasnya sinar matahari masuk kedalam gedung tersebut. Oleh karena itu untuk penerangan ruangannya menggunakan cahaya lampu yang menyala setiap hari selama lebih dari 18 jam dengan itensitas cahaya yang cukup tinggi sebagai penerangan. Penelitian ini bertujuan untuk menindak lanjuti permasalahan energi baru terbarukan pada system Photovoltaic. Penggunaan energi listrik di Indonesia terus mengalamai peningkatan [1]. Untuk memanfaatkan energi listrik baru terbarukan dengan memanfaatkan sumber intensitas cahaya dari lampu yang dapat dikonversikan secara langsung menjadi energi listrik menggunakan photovoltaic. Photovoltaic dapat bekerja secara maksimal apabila mendapatkan cahaya yang cukup untuk menghasilkan sumber energi listrik. Kemajuan penelitian dalam ilmu material meningkatkan efisiensi sistem fotovoltaik secara bertahap [2]. Sel surya memiliki kendala daya keluaran yang tidak cukup besar dan salah satu metode pengoptimalan sel surya adalah dengan menggunakan cermin pemantul sinar matahari (reflector) [3]. Berbagai jenis sel surya tersedia untuk disesuaikan dengan sumber pencahayaan dan intensitas yang berbeda [4]. Dari berbagai penelitian sebelumnya menunjukkan bahwa perbedaan efisiensi sel surya terhadap efek intensitas dan suhu permukaan panel surya terhadap berbagai jenis sel surya [5]. Intensitas cahaya adalah salah satu 
faktornya yang mempengaruhi efisiensi sel surya pada sel surya silikon monokristal [6]. Pemanfaatan itensitas cahaya lampu pada penelitian kali ini peneliti akan membahas cahaya pada gedung bertingkat yang akan dimaksimalkan dengan menggunakan photovoltaic sebagai reflektor untuk mengasilkan energi listrik yang dapat digunakan sebagi sumber listrik pengganti pada saat sumber listrik utama sedang terputus atau mengalami gangguan. Penggunaan lampu ini sebagai media pengganti matahari dengan metode reflektor supaya intensitas cahaya yang masuk terhadap photovoltaic agar fokus terhadap reflector.

Berdasarkan hal tersebut maka penelitian ini akan di buat suatu rancang bangun sistem yaitu:

1. Bagaimana merencanakan dan membuat suatu alat yang dapat di fungsikan untuk pemanenan energi harvesting dengan panel surya.

2. Menganalisa intensitas radiasi cahaya lampu tehadap panel surya.

3. Perbandingan jenis lampu terhadap itensitas cahaya.

4. Mengetahui efisiensi panel surya jika di sinari oleh lampu.

5. Output yang dihasilkan panel surya terhadap cayaha lampu.

Agar permasalahan tidak terlau luas, maka ruang lingkup penelitian ini dibatasi pada:

1. Jenis lampu yang digunakan jenis LED dan Pendar.

2. Photovoltaic yang digunakan monocrystaline sebesar $6 \mathrm{Wp}$.

3. Pengontrolan supply baterai

4. Nilai Intensitas cahaya lampu yang diukur menggunakan Lux meter.

Adapun tujuan dari penelitian ini adalah:

1. Dapat membuat perancangan reflektor lampu dengan panel surya.

2. Dapat mengetahui efisiensi panel surya terhadap cahaya lampu.

3. Dapat membandingkan output yang dihasilkan panel surya terhadap jenis lampu.

4. Pemanenan energi harvesting yang dihasilkan dari intensitas lampu.

\section{TINJAUAN PUSTAKA}

Energy Harvesting (Pemanenan Energi) salah satu solusi dalam permasalahan krisis energi adalah mengembangkan potensi energi alternatif yang disebut energi terbarukan. prinsip kekekalan energi dimana substansi energi tak bisa dihilang, namun hanya dapat diubah ke bentuk lain. Maka terciptalah suatu gebrakan yang disebut Energy Harvesting atau Pemanenan energi. Suatu metode untuk mengambil atau menangkap energi terbuang dari pelepasan energi yang terdapat di lingkungan dan mengubahnya menjadi energi sekunder yang dapat disimpan atau dipakai langsung. Energi terbuang ini dapat berupa energi kinetis berupa : getaran, putaran, energi bunyi berupa suara, energi panas, dll [7].

Tujuan Energy Harvesting

1. Meningkatkan efisiensi energi system.

2. Menyediakan energi yang kecil untuk peralatan pelengkap berdaya kecil.

3. Memperoleh energi baru yang siap pakai

Kelebihan energy harvesting

1. Minim polusi tidak memerlukan penggantian baterai

2. Dapat diaplikasikan ditempat dengan luas terbatas

3. Dapat mengatasi krisis energi dikondisi darurat Kualitas Pemanenan Energy

1. Accumulating Jumlah energi yang dapat diterima

2. Storaging Jumlah energi yang dapat disimpan

3. Converting Jumlah energi yang dapat disuplai ke beban.

Cahaya memiliki suatu peranan penting di dalam kehidupan sehari-hari seperti misalnya cahaya buatan atau bisa disebut juga cahaya lampu yang dimana iluminansinya cahaya bergantung pada jarak terhadap sumber cahaya tersebut. Intensitas cahaya adalah sebuah iluminansi cayaha yang berhubungan jarak serta sumber cahayanya.[8]. Pemanfaatan lampu pada era saat ini merupakan suatu kebutuhan yang sangat penting dalam kehidupan sehari-hari. Pada penelitian ini dikembangkan model pemanenan energi dengan memaksimalkan intensitas cahaya yang digunakan. Rencanaan penerangan pada suatu tempat harus mempertimbangkan beberapa faktor antara lain intensitas penerangan saat digunakan untuk bekerja, intensitas penerangan ruang pada umumnya, biaya instalasi, biaya pemakaian energi dan biaya pemeliharaannya. Perlu diperhatikan, perbedaan intensitas penerangan yang terlalu besar antara bidang kerja dan sekitarnya harus dihindari karena mata kita akan memerlukan daya yang besar untuk beradaptasi dengan kondisi tersebut yang menyebabkan mata mudah lelah.

Untuk mendapatkan pencahayaan yang sesuai dalam suatu ruang, maka diperlukan sistem pencahayaan yang tepat sesuai dengan kebutuhannya. Sistem pencahayaan di ruangan, termasuk di tempat kerja dapat dibedakan menjadi 5 macam yaitu sebagai berikut [9], [8].

1. Sistem Pencahayaan Langsung (direct lighting)

Pada sistem ini 90-100\% cahaya diarahkan secara langsung ke benda yang perlu diterangi. Sistem ini dinilai paling efektif dalam mengatur pencahayaan, tetapi ada kelemahannya karena dapat 
RESISTOR (Elektronika Kendali Telekomunikasi Tenaga Listrik Komputer) Vol. 3 No. 2 e-ISSN : 2621-9700, p-ISSN : 2654-2684

menimbulkan bahaya serta kesilauan yang mengganggu.

2. Pencahayaan Semi Langsung (semi direct lighting)

Pada sistem ini 60-90\% cahaya diarahkan langsung pada benda yang perlu diterangi, sedangkan sisanya dipantulkan ke langit-langit dan dinding. Dengan sistem ini kelemahan sistem pencahayaan langsung dapat dikurangi.

3. Sistem Pencahayaan Difus (general diffus lighting)

Pada sistem ini setengah cahaya $40-60 \%$ diarahkan pada benda yang perlu disinari, sedangka sisanya dipantulka ke langit-langit dan dindng. Dalam pencahayaan sistem ini termasuk sistem directindirect yakni memancarkan setengah cahaya ke bawah dan sisanya keatas. Pada sistem ini masalah bayangan dan kesilauan masih ditemui.

4. Sistem Pencahayaan Semi Tidak Langsung (semi indirect lighting)

Pada sistem ini 60-90\% cahaya diarahkan ke langit-langit dan dinding bagian atas, sedangkan sisanya diarahkan ke bagian bawah. Untuk hasil yang optimal disarankan langit-langit perlu diberikan perhatian serta dirawat dengan baik.

5. Sistem Pencahayaan Tidak Langsung (indirect lighting)

Pada sistem ini 90-100\% cahaya diarahkan ke langit-langit dan dinding bagian atas kemudian dipantulkan untuk menerangi seluruh ruangan. Agar seluruh langit-langit dapat menjadi sumber cahaya, perlu diberikan perhatian dan pemeliharaan yang baik.

Pada dasarnya dalam perhitungan jumlah titik lampu pada suatu ruang dipengaruhi oleh banyak faktor, antara lain dimensi ruang, kegunaan / fungsi ruang, warna dinding, type armature yang akan digunakan, dan masih banyak lagi [9].

Tabel 1 Daya pencahayaan maksimum menurut SNI.

\begin{tabular}{|c|c|}
\hline Ruang Kantor/ Industri & 15 watt $/ \mathrm{m}^{2}$ \\
\hline Rumah Tinggal & 10 watt $/ \mathrm{m}^{2}$ \\
\hline Toko & $20-40$ watt $/ \mathrm{m}^{2}$ \\
\hline Hotel & $10-30$ watt $/ \mathrm{m}^{2}$ \\
\hline Sekolah & $15-30$ watt $/ \mathrm{m}^{2}$ \\
\hline Rumah sakit & $10-30$ watt $/ \mathrm{m}^{2}$ \\
\hline
\end{tabular}

Tabel 2 Kebutuhan iluminansi berdasarkan lingkungan kerja.

\begin{tabular}{|l|l|l|}
\hline No. & Lingkungan Kerja & $\begin{array}{l}\text { Iliminansi } \\
\text { (lux) }\end{array}$ \\
\hline
\end{tabular}

Dimana:

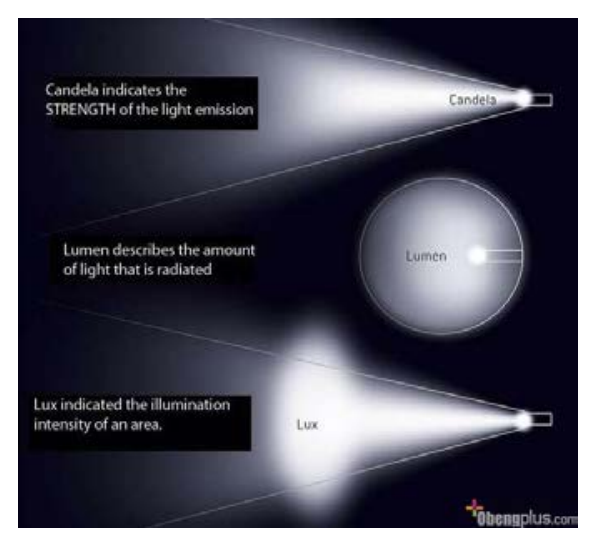

Gambar 1 Perbedaan Satuan Cahaya.

Rumus Satuan Cahaya

1. Intensitas Cahaya

Intensitas Cahaya adalah jumlah energy yang radisasi yang dipancarkan sebagai cahaya ke suatu jurusan tertentu satauannya candela $(c d)$ [8].

Rumusnya :

$$
I=\frac{\Phi}{\omega} c d
$$

$\mathrm{I}=$ intensitas cahaya (cd) 
RESISTOR (Elektronika Kendali Telekomunikasi Tenaga Listrik Komputer) Vol. 3 No. 2 e-ISSN : 2621-9700, p-ISSN : 2654-2684

$\Phi=$ flux cahaya (lm)

$\omega=$ streradian suatu sudut ruang.

Suatu sumber cahaya yang berbentuk bola, luas permukaannya sama dengan $4 \pi r^{2}$, maka disekitar titik tengah bola dapat diletakan $4 \pi$ sudut ruang (4 bagian ruang) yang masing-masing sama dengan satu streradian. Jumlah streradian suatu sudut ruang dinyatakan dengan lambang $\omega$ (omega).

2. Flux cahaya

Flux cahaya adalah jumlah cahaya yang diapncarkan oleh suatu sumber cahaya setiap detik, satuannya lumen $(\mathrm{lm})$ [8].

Dari rumus :

Didapat :

$$
I=\frac{\Phi}{\omega} c d
$$

$\Phi=\omega . I \mathrm{~lm}$, jika $\omega=4 \pi$,maka

$\Phi=4 \pi$. I lm, jika I = 1, maka

$\Phi=4 \pi \mathrm{lm}$

3. Intensitas penerangan

Intensitas penerangan adalah flux cahaya yang jatuh pada bidang setiap $\mathrm{m}^{2}$ satuannya adalah lux (lx) dan lambangnya E [8].

$$
1 \text { lux }=1 \text { lumen per } m^{2}
$$

Jika suatu bidang yang luasnya $\mathrm{A} \mathrm{m}^{2}$, diterangi dengan $\Phi$ lumen, maka besarnya intensitas penerangan rata-rata di bidang tersebut sama dengan

$$
E_{\text {rata-rata }}=\frac{\Phi}{A} \operatorname{lux}
$$

Apabila luas bidang $10 \mathrm{~m}^{2}$ diterangi dengan 1000 lumen, maka didapat :

$$
E_{\text {rata-rata }}=\frac{\Phi}{A}=\frac{1000}{10}=100 \text { lux }
$$

Intensitas penerangan di suatu bidang karena suatu sumber cahaya dengan intensitas I, berkurang dengan kuadrat dari jarak antara sumber cahaya dan bidang itu (hukum kuadrat).

Rumus:

dimana:

$$
E p=\frac{I}{r^{2}} \operatorname{lux}
$$

Ep = intensitas penerangan di suatu titik $\mathrm{P}$ dari bidang yang diterangi, dinyatakan dalam satuan lux

$\mathrm{I}=$ intensitas sumber cahaya dalam satuan candela

$\mathrm{r}=$ jarak dari sumber cahaya ke titik $\mathrm{P}$, dinyatakan dalam meter.

Luminasi adalah suatu ukuran untuk terang suatu benda. Luminasi yang terlalu besar akan menyilaukan mata, seperti lampu pijar tanpa armatur (tempat merefleksikan cahaya) [8].
Luminasi L suatu sumber cahaya atau suatu permukaan yang memantulkan cahaya ialah intensitas cahayanya dibagi dengan luas semu permukaan [8].

Rumus:

dimana:

$$
L=\frac{I}{A s} c d / \mathrm{cm}^{2}
$$

$\mathrm{L}=$ luminasi dalam satuan $c d / \mathrm{cm}^{2}$

$\mathrm{I}=$ intensitas sumber cahaya dalam satuan candela

$\mathrm{A}_{\mathrm{s}}=$ luas permukaan semu $\mathrm{cm}^{2}$

Kalau luminasinya kecil dapat menggunakan satuan $c d / \mathrm{cm}^{2}$

$$
{ }^{1} \mathrm{~cd} / \mathrm{cm}^{2}=10.000 \mathrm{~cd} / \mathrm{cm}^{2}
$$

\section{PERENCANAAN SISTEM DAN PERANCANGAN ALAT}

Dibawah ini adalah gambar rangkaian penelitian serta perancangan alat yang akan di lakukan dalam penelitian, serta penelitian dapat berjalan dengan baik.

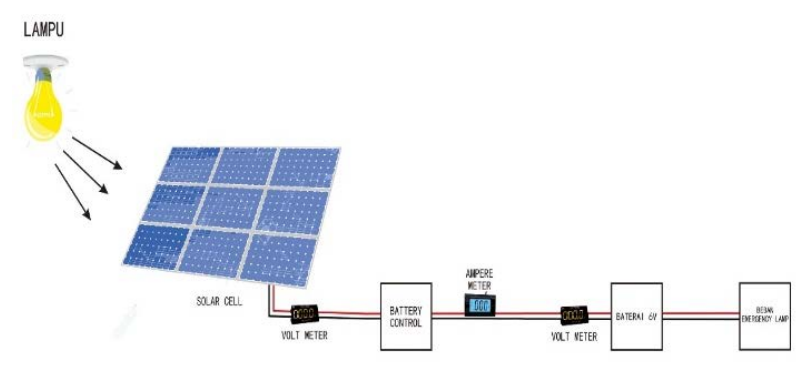

Gambar 2 Rangkaian penelitian.

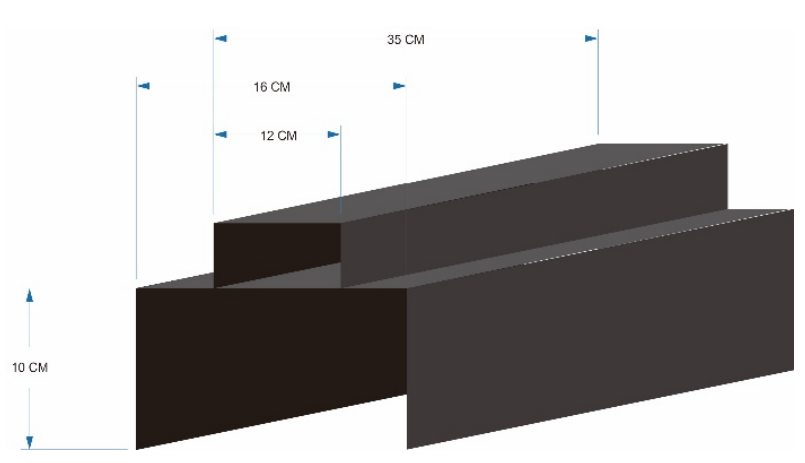

Gambar 3 Perancangan panel surya terhadap lampu led. 
RESISTOR (Elektronika Kendali Telekomunikasi Tenaga Listrik Komputer) Vol. 3 No. 2 e-ISSN : 2621-9700, p-ISSN : 2654-2684

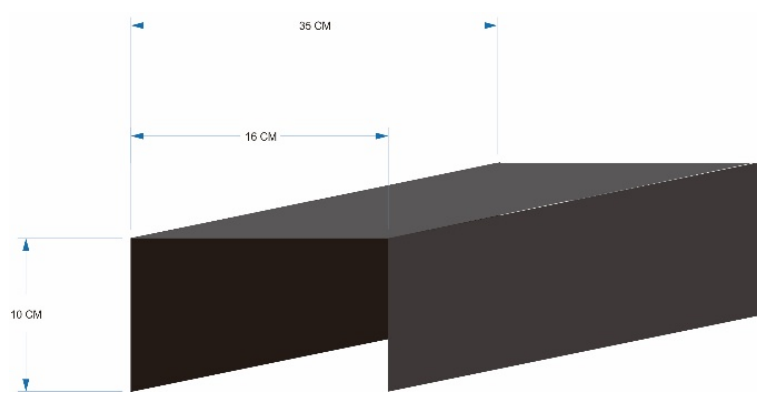

Gambar 4 Perancangan panel surya terhadap lampu pijar.

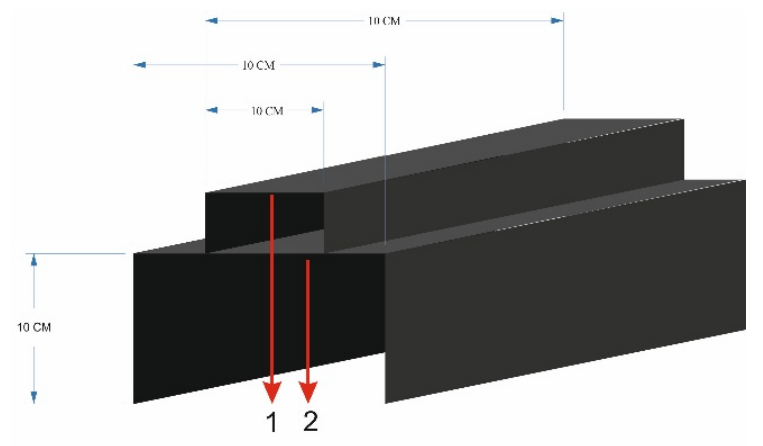

Ket:
1: Tempat Baterai dan Kontrol Batera

Gambar 5 Perancangan lampu emergency dan penempatan baterai serta kontrol baterai.

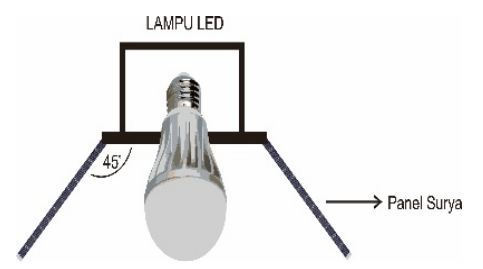

Gambar 6 Perancangan lampu led dengan panel surya $45^{\circ}$.

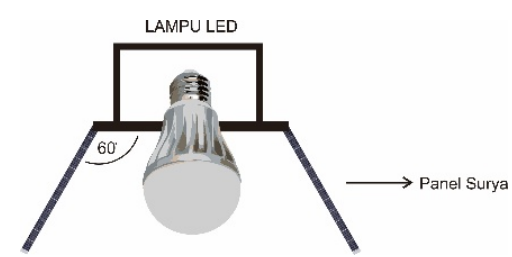

Gambar 7 Perancangan lampu led dengan panel surya $60^{\circ}$.

LAMPU LED

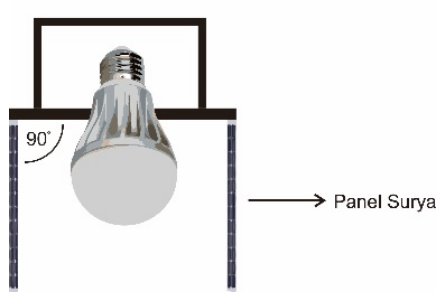

Gambar 8 Perancangan lampu led dengan panel surya $90^{\circ}$.

LAMPU PIJAR

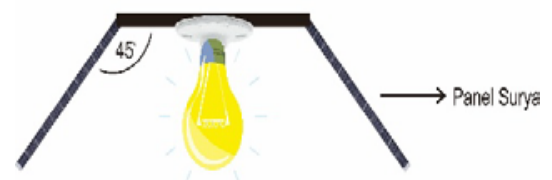

Gambar 9 Perancangan lampu pijar dengan panel surya $45^{\circ}$.

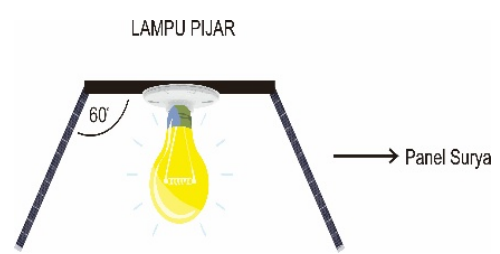

Gambar 10 Perancangan lampu pijar dengan panel surya $60^{\circ}$.

LAMPU PIJAR

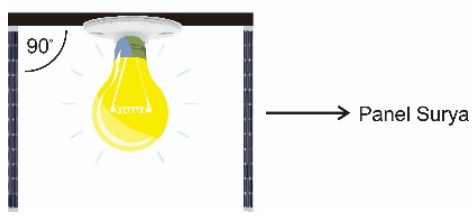

Gambar 11 Perancangan lampu pijar dengan panel surya $90^{\circ}$.

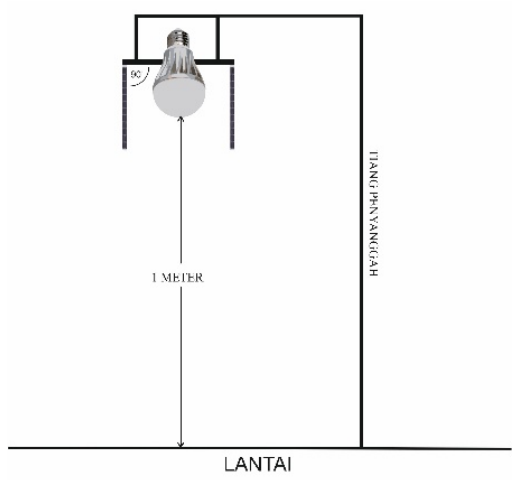

Gambar 12 Percobaan dengan mengunakan lampu led. 
RESISTOR (Elektronika Kendali Telekomunikasi Tenaga Listrik Komputer) Vol. 3 No. 2 e-ISSN : 2621-9700, p-ISSN : 2654-2684

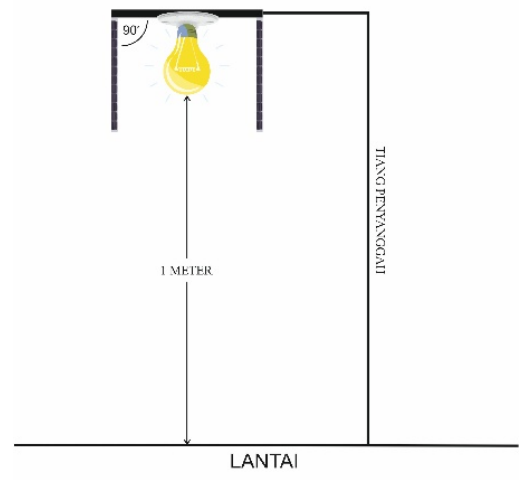

Gambar 13 Percobaan dengan mengunakan lampu pijar.

Untuk memudahkan penelitian makan peneliti membutuhkan flowchart yang diperlukan untuk mempermudah dan mengatur alur penelitian yang akan di laksanakan. Dan juga dapat memperjelas bagaimana proses perancangan dan penilitian yang dilakuan.
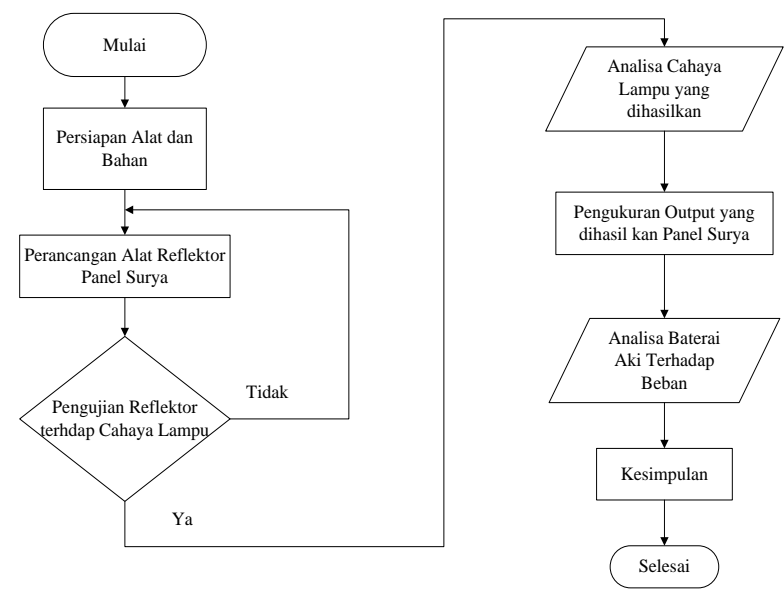

Gambar 14 Flowchart penelitian.

\section{PENGUJIAN DAN ANALISA}

Berdasarkan pengujian terhadap sudut kemiringan reflector panel surya di dapatkan hasil pengukuran keluaran dari panel surya dengan sumber cahaya lampu led dan lampu pijar, percobaan ini bertujuan agar mendapatkan hasil yang terbaik. Dari pengujian ini diketahui yang di hasilkan oleh lampu led dan lampu pijar utama sebagai sumber utama penyinaran panel surya. data yang di ambil dari pengukuran dan pengujuan reflektor panel surya ini adalah tegangan dan arus dari beberapa kemiringan sudut $<{ }^{\circ}$ dengan sumber lampu led dan lampu pijar.

Tabel 3 Pengukuran rangkaian dengan sudut $45^{\circ}$.

\begin{tabular}{|c|c|c|c|}
\hline $\begin{array}{c}\text { Sudut } \\
45^{\circ}\end{array}$ & $\begin{array}{c}\text { Tegangan } \\
\text { (Volt) }\end{array}$ & $\begin{array}{c}\text { Arus } \\
\text { (Ampere) }\end{array}$ & $\begin{array}{c}\text { Daya } \\
\text { (Watt) }\end{array}$ \\
\hline Seri & 22.42 & 0.009 & 0.16 \\
\hline Paralel & 5.63 & 0.010 & 0.06 \\
\hline $\begin{array}{c}\text { Seri } \\
\text { Paralel }\end{array}$ & 11.22 & 0.013 & 0.15 \\
\hline
\end{tabular}

Tabel 4 Pengukuran rangkaian dengan sudut $60^{\circ}$.

\begin{tabular}{|c|c|c|c|}
\hline $\begin{array}{c}\text { Sudut } \\
60^{\circ}\end{array}$ & $\begin{array}{c}\text { Tegangan } \\
\text { (Volt) }\end{array}$ & $\begin{array}{c}\text { Arus } \\
\text { (Ampere) }\end{array}$ & $\begin{array}{c}\text { Daya } \\
\text { (Watt) }\end{array}$ \\
\hline Seri & 23.78 & 0.013 & 0.31 \\
\hline Paralel & 5.92 & 0.034 & 0.20 \\
\hline $\begin{array}{c}\text { Seri } \\
\text { Paralel }\end{array}$ & 11.89 & 0.023 & 0.27 \\
\hline
\end{tabular}

Tabel 5 Pengukuran rangkaian dengan sudut $90^{\circ}$.

\begin{tabular}{|c|c|c|c|}
\hline $\begin{array}{c}\text { Sudut } \\
90^{\circ}\end{array}$ & $\begin{array}{c}\text { Tegangan } \\
\text { (Volt) }\end{array}$ & $\begin{array}{c}\text { Arus } \\
\text { (Ampere) }\end{array}$ & $\begin{array}{c}\text { Daya } \\
\text { (Watt) }\end{array}$ \\
\hline Seri & 24.78 & 0.021 & 0.52 \\
\hline Paralel & 6.19 & 0.067 & 0.41 \\
\hline $\begin{array}{c}\text { Seri } \\
\text { Paralel }\end{array}$ & 12.53 & 0.045 & 0.56 \\
\hline
\end{tabular}

Dengan mengetahui keluaran daya panel mengunakan reflektor panel surya dengan lampu Led output tebaik yang dihasilkan adalah dengan rangkaian Seri paralel dengan sudut kemiringan $90^{\circ}$.

Tabel 6 Pengukuran rangkaian dengan sudut $45^{\circ}$.

\begin{tabular}{|c|c|c|c|}
\hline $\begin{array}{c}\text { Sudut } \\
45^{\circ}\end{array}$ & $\begin{array}{c}\text { Tegangan } \\
\text { (Volt) }\end{array}$ & $\begin{array}{c}\text { Arus } \\
\text { (Ampere) }\end{array}$ & $\begin{array}{c}\text { Daya } \\
\text { (Watt) }\end{array}$ \\
\hline Seri & 23.32 & 0.011 & 0.26 \\
\hline Paralel & 5.82 & 0.042 & 0.24 \\
\hline $\begin{array}{c}\text { Seri } \\
\text { Paralel }\end{array}$ & 11.61 & 0.022 & 0.25 \\
\hline
\end{tabular}

Tabel 7 Pengukuran rangkaian dengan Sudut $60^{\circ}$.

\begin{tabular}{|c|c|c|c|}
\hline $\begin{array}{c}\text { Sudut } \\
60^{\circ}\end{array}$ & $\begin{array}{c}\text { Tegangan } \\
\text { (Volt) }\end{array}$ & $\begin{array}{c}\text { Arus } \\
\text { (Ampere) }\end{array}$ & $\begin{array}{c}\text { Daya } \\
\text { (Watt) }\end{array}$ \\
\hline Seri & 23.63 & 0.013 & 0.31 \\
\hline Paralel & 5.87 & 0.049 & 0.29 \\
\hline $\begin{array}{c}\text { Seri } \\
\text { Paralel }\end{array}$ & 11.75 & 0.026 & 0.30 \\
\hline
\end{tabular}

Tabel 8 Pengukuran rangkaian dengan sudut $90^{\circ}$.

\begin{tabular}{|c|c|c|c|}
\hline $\begin{array}{c}\text { Sudut } \\
90^{\circ}\end{array}$ & $\begin{array}{c}\text { Tegangan } \\
\text { (Volt) }\end{array}$ & $\begin{array}{c}\text { Arus } \\
\text { (Ampere) }\end{array}$ & $\begin{array}{c}\text { Daya } \\
\text { (Watt) }\end{array}$ \\
\hline Seri & 24.38 & 0.019 & 0.46 \\
\hline Paralel & 6.02 & 0.032 & 0.19 \\
\hline
\end{tabular}


RESISTOR (Elektronika Kendali Telekomunikasi Tenaga Listrik Komputer) Vol. 3 No. 2 e-ISSN : 2621-9700, p-ISSN : 2654-2684

\begin{tabular}{|c|c|c|c|}
\hline $\begin{array}{c}\text { Seri } \\
\text { Paralel }\end{array}$ & 12.16 & 0.033 & 0.40 \\
\hline
\end{tabular}

Dengan mengetahui keluaran daya panel mengunakan reflektor panel surya dengan lampu Pijar output tebaik yang dihasilkan adalah dengan rangkaian Seri paralel dengan sudut kemiringan $90^{\circ}$.

Pengujian dengan baterai bertujuan untuk melihat waktu penyimpanan yang di butuhkan sampai baterai terisi penuh dengan data sebelumnya dengan output terbaik mengunakan sudut kemiringan reflektor $90^{\circ}$ mengunakan rangkaian seri parallel.

Pada pengujian menggunakan lampu led dengan sudut $90^{\circ}$ hasil yang di peroleh untuk mengisi baterai 6v selama 3 hari 14 jam atau total keseluruhan adalah 86 jam.

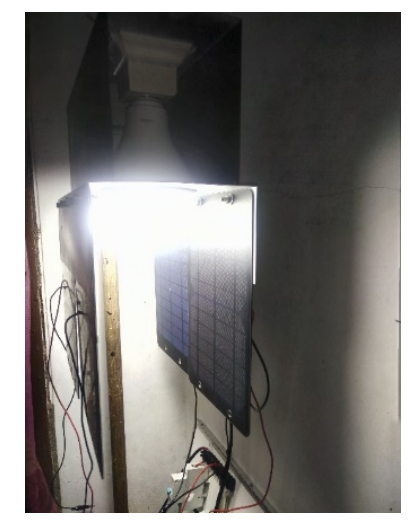

Gambar 15 Pengujian reflektor $90^{\circ}$ dengan menggunakan lampu Led.

Berdasarkan hasil pengukuran intensitas cahaya yang di peroleh panel surya dengan mengunakan lampu Led sebesar $22,7 \mathrm{~W} / \mathrm{m}^{2}$ dengan mengunaka solar power meter.

Berdasarkan hasil pengujian diatas maka dapat dihitung efisiensi panel surya dengan penyinaran yang di peroleh oleh lampu Led

$$
\eta=\frac{P \max (\text { maximum power point })}{E \text { (incident radiation flix) } x \text { Ac (area of colector })} \times 100 \%
$$

\section{Dimana}

$\eta=$ Efisiensi $100 \%$

Pmax $=$ Maximum Power Point $(\mathrm{W})$

$\mathrm{E}=$ Radiasi Matahari $\left(\mathrm{W} / \mathrm{m}^{2}\right)$

Ac $=$ Luas Permukaan Panel Surya $\left(\mathrm{m}^{2}\right)$

Maka efisiensi panel surya Rangkaian Seri Paralel $90^{\circ}$ dapat dihitung sebagai berikut :

$$
\begin{aligned}
& \eta=\frac{P \max (\text { maximum power point })}{E \text { (incident radiation flix) } \times \text { Ac (area of colector })} \times 100 \% \\
& \eta=\frac{0,56 W}{22,7 \mathrm{~W} / \mathrm{m}^{2} \times(0,35 \times 0,48)} \times 100 \% \\
& \eta=\frac{0,56 W}{3,8136} \times 100 \%
\end{aligned}
$$

$\eta=14,68 \%$

Pada pengujian menggunakan lampu Led dengan sudut $90^{\circ}$ hasil yang di peroleh untuk mengisi baterai $6 \mathrm{v}$ selama 5 hari 3 jam atau total keseluruhan adalah 123 jam.

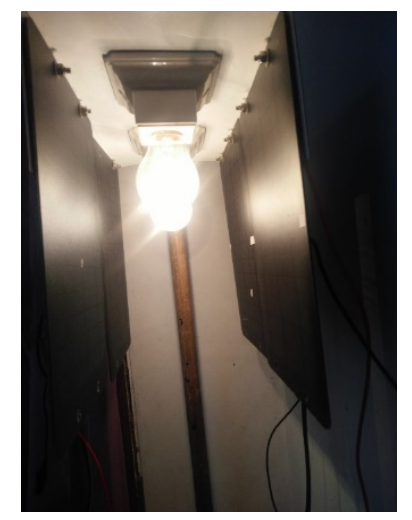

Gambar 16 Pengujian reflektor $90^{\circ}$ dengan menggunaka lampu pijar.

Berdasarkan hasil pengukuran intensitas cahaya yang di peroleh panel surya dengan mengunakan lampu Pijar sebesar 28,8W/m² dengan mengunaka solar power meter.

Berdasarkan hasil pengujian diatas maka dapat dihitung efisiensi panel surya dengan penyinaran yang di peroleh oleh lampu Pijar.

$$
\begin{aligned}
& \eta=\frac{\text { Pmax (maximum power point })}{E \text { (incident radiation flix) } x \text { Ac (area of colector) }} \times 100 \% \\
& \text { Dimana } \\
& \eta=\text { Efisiensi } 100 \% \\
& \text { Pmax = Maximum Power Point (W) } \\
& E=\text { Radiasi Matahari }\left(\mathrm{W} / \mathrm{m}^{2}\right) \\
& \text { Ac = Luas Permukaan Panel Surya }\left(\mathrm{m}^{2}\right)
\end{aligned}
$$

Maka efisiensi panel surya Rangkaian Seri Paralel $90^{\circ}$ dapat dihitung sebagai berikut :

$\eta=\frac{P \max (\text { maximum power point })}{E \text { (incident radiation flix) } x \text { Ac (area of colector) }} \times 100 \%$

$$
\begin{aligned}
\eta & =\frac{0,40 \mathrm{~W}}{28,8 \mathrm{~W} / \mathrm{m}^{2} \times(0,35 \times 0,48)} \times 100 \% \\
\eta & =\frac{0,40 \mathrm{~W}}{4,8384} \times 100 \%
\end{aligned}
$$$$
\eta=8,62 \%
$$

Grafik dibawah ini untuk melihat perbedaaan antara Reflektor dengan mengunakan lampu Led dan Reflektor dengan menggunakan Lampu pijar Tujuannya agar bisa membandingkan hasil dari data diatas yang telah diperoleh sebab perbedaan akan terlihat jelas dengan grafik di bawah ini. 
RESISTOR (Elektronika Kendali Telekomunikasi Tenaga Listrik Komputer) Vol. 3 No. 2 e-ISSN : 2621-9700, p-ISSN : 2654-2684



Gambar 17 Grafik perbandingan waktu vs tegangan panel.

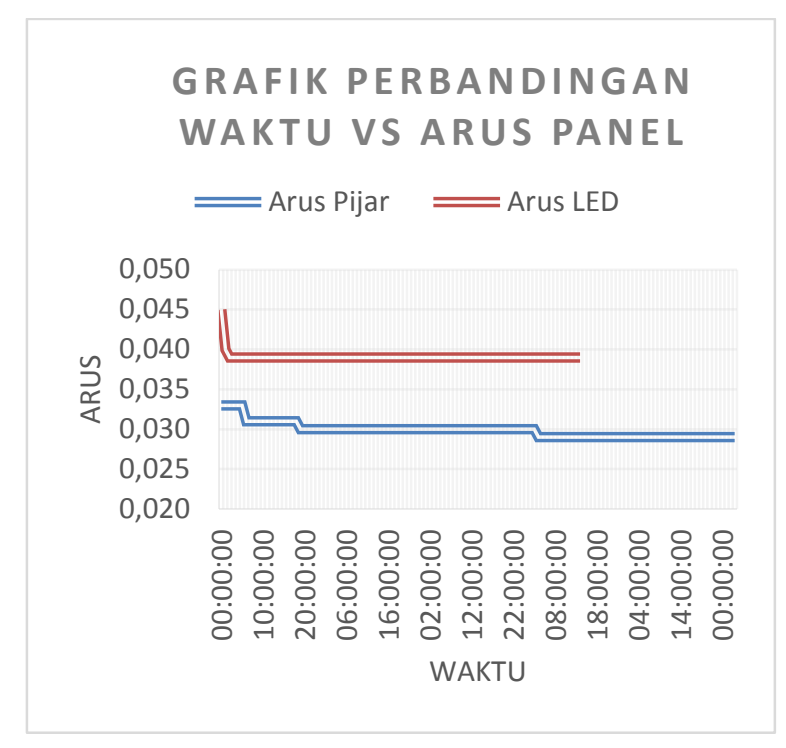

Gambar 18 Grafik perbandingan waktu vs arus panel.

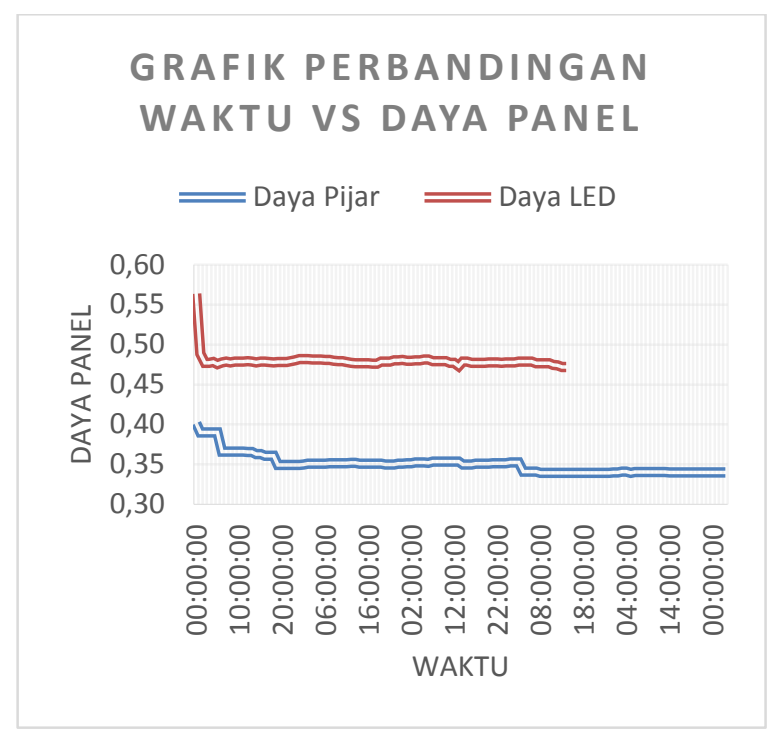

Gambar 19 Grafik perbandingan waktu vs daya panel.

\section{GRAFIK PERBANDINGAN \\ WAKTU VS TEGANGAN \\ BATERAI}

$$
\begin{aligned}
& \overline{=} \text { Tegangan Baterai Pijar } \\
& =\text { Tegangan Baterai LED }
\end{aligned}
$$

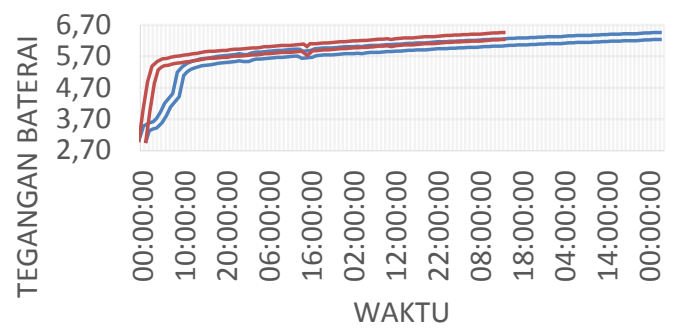

Gambar 20 Grafik perbandingan waktu vs tegangan baterai. 
RESISTOR (Elektronika Kendali Telekomunikasi Tenaga Listrik Komputer) Vol. 3 No. 2 e-ISSN : 2621-9700, p-ISSN : 2654-2684

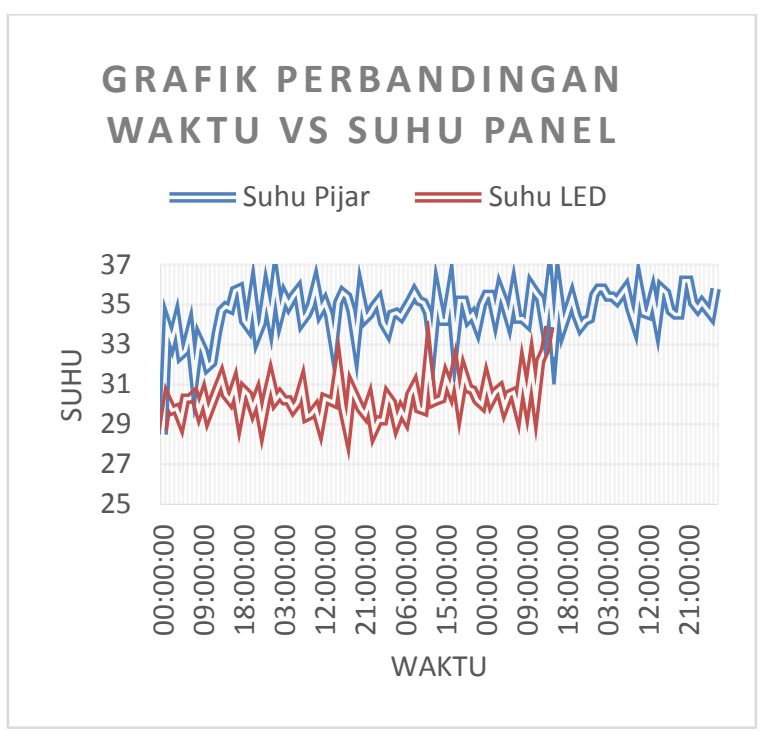

Gambar 21 Perbandingan waktu vs suhu panel.

Dalam pengujian ini adalah percobaan baterai digunakan untuk menyalakan lampu emergency maka akan dilihat seberapa lama dalam menggunakan lampu tersebut dapat dilihat pada tabel di bawah ini pengguaan pada saat baterai terisi 6,35 volt menghidupkan lampu DC Led sebesar 5 Volt 10 Watt selama 7 jam .

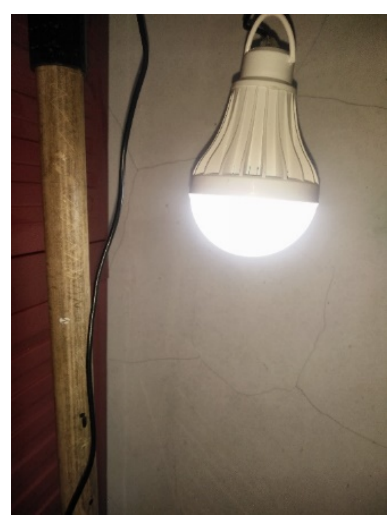

Gambar 22 Pengujian lampu emergency dengan baterai.

Tabel 9 Hasil Pengujian lampu emergency dengan baterai.

\begin{tabular}{|c|c|c|c|c|}
\hline Waktu & $\begin{array}{c}\text { Teg. } \\
\text { Baterai } \\
\text { (V) }\end{array}$ & $\begin{array}{c}\text { Arus } \\
\text { Baterai } \\
(\mathrm{A})\end{array}$ & $\begin{array}{c}\text { Int. } \\
\text { Cahaya } \\
\text { (Lux) }\end{array}$ & $\begin{array}{c}\text { Daya } \\
\text { (W) }\end{array}$ \\
\hline $17: 00$ & 6,35 & 1,36 & 73,06 & 8,64 \\
\hline $18: 00$ & 5,70 & 1,24 & 53,13 & 7,07 \\
\hline $19: 00$ & 4,40 & 0,65 & 44,42 & 2,86 \\
\hline $20: 00$ & 3,45 & 0,27 & 24,78 & 0,93 \\
\hline $21: 00$ & 3,15 & 0,16 & 16,06 & 0,50 \\
\hline $22: 00$ & 2,99 & 0,10 & 10,94 & 0,30 \\
\hline
\end{tabular}

\begin{tabular}{|l|l|l|l|l|}
$23: 00$ & 2,88 & 0,07 & 8,18 & 0,20 \\
\hline $00: 00$ & 2,82 & 0,05 & 6,27 & 0,14 \\
\hline
\end{tabular}

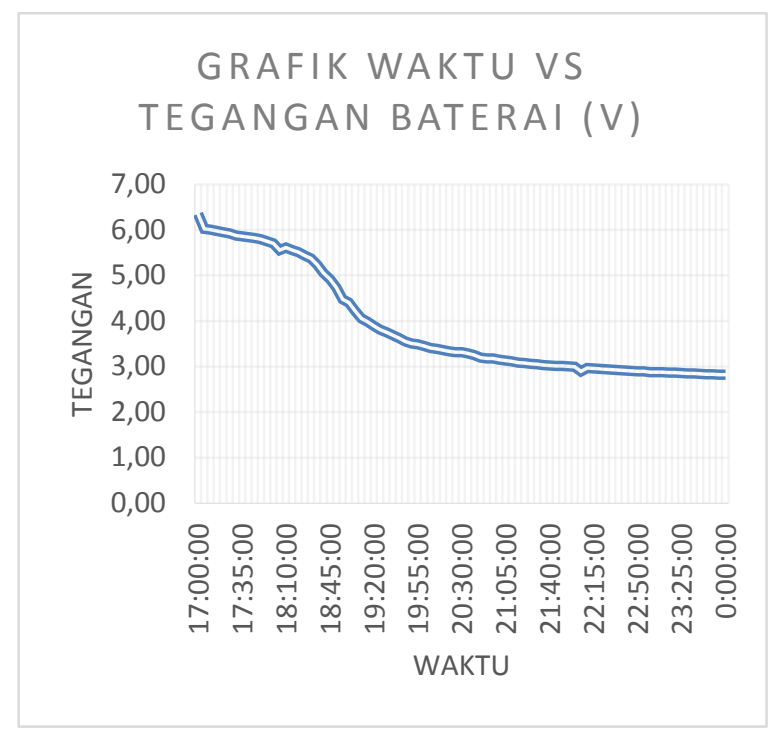

Gambar 23 Grafik waktu vs tegangan baterai.

\section{GRAFIK WAKTU VS ARUS BATERAI (A)}

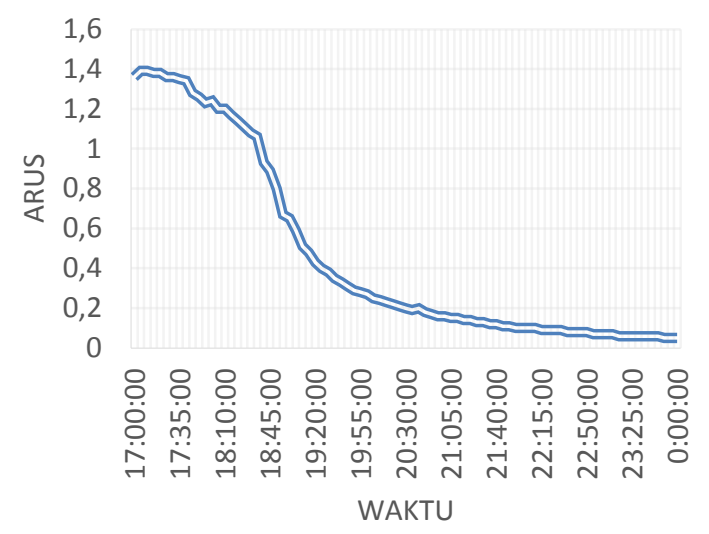

Gambar 24 Grafik waktu vs arus baterai. 
RESISTOR (Elektronika Kendali Telekomunikasi Tenaga Listrik Komputer) Vol. 3 No. 2 e-ISSN : 2621-9700, p-ISSN : 2654-2684

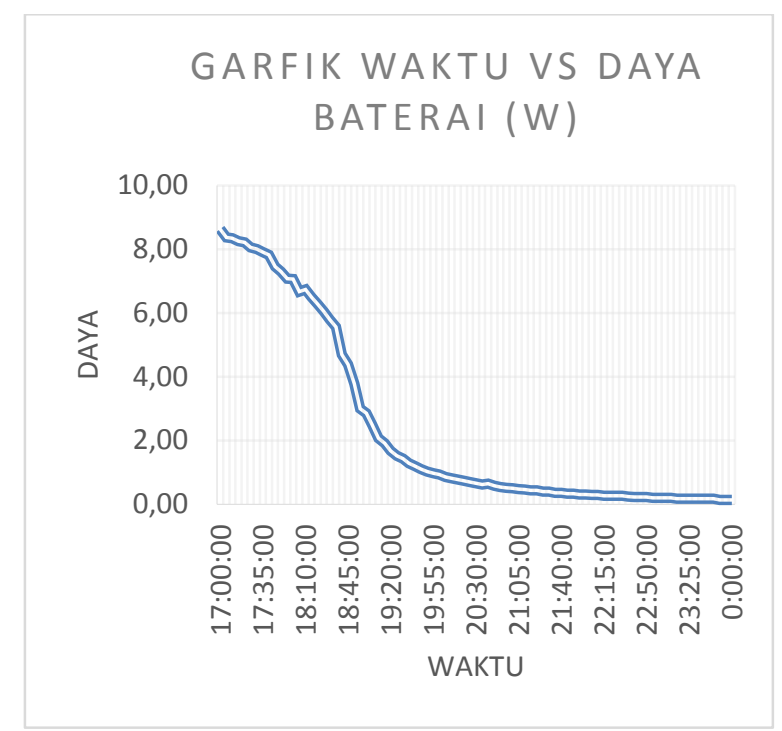

Gambar 25 Grafik waktu vs daya baterai.

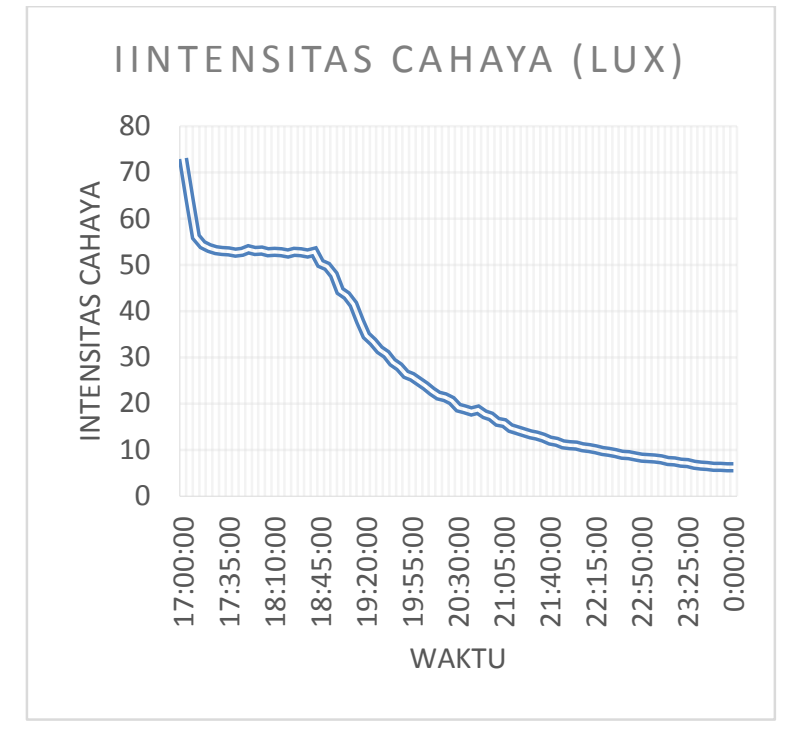

Gambar 26 Grafik waktu vs intensitas cahaya.

\section{KESIMPULAN}

Dari hasil dari pengujian dan penelitian alat dengan judul "Pemanfaatan Intensitas Radiasi Cahaya Lampu Dengan Reflektor Panel Surya Sebagai Energy_Harvesting” maka dapat disimpulkan sebagai berikut:

1. Dari uji coba ini output yang paling baik menggunakan lampu led dan sudut sangat mempengaruhi output yang dihasilkan panel surya.

2. Karena dengan sudut $90^{\circ}$ cahaya lampu led lebih menyebar dan panel surya lebih banyak tekena cahaya lampu dan menghasilkan daya sebesar 0.56 watt berbeda jika dibandingakan lampu pijar yang menghasilkan dayasebesar 0.40 watt.

3. Untuk sudut optimalnya sendiri adalah $45^{\circ}$ sampai dengan $60^{\circ}$ karena cahaya yang dihasilkan lebih meluas serta peniaran pada objek juga maksimal namun titik fokus masih dapat berbayang.

4. Dengan hasil uji coba ini apabila di aplikasikan sebaiknya digunakan untuk keperluan yang sangat detail karna panel surya memerlukan sumber cahaya sangat besar dan lampu memberikan titik fokus yang maksimal.

5. Intensitas lampu pijar dengan sudut $90^{\circ}$ lebih tinggi tetapi cahaya yang diberikan ke panel kurang merata oleh karna itu lampu pijar kurang bagus jika untuk pemanenan energi (energy harvesting). karna cahaya yang dihasil kan kurang menyebar dan penel surya tidak sepenuh nya terpapar cahaya lampu

6. Dan dibutuhkan waktu yang cukup lama untuk mengisi baterai jika menggunakan lampu pijar dibandingkan lampu led.

7. Energy Harvesting pada alat ini mengasilkan energi sangat kecil namun bisa digunakan dan dapat mengasilkan energi baru.

8. Contoh penentuan kapasitas baterai jika ingin menyalakan lampu emergency selama 4 jam dengan beban lampu yang digunakan 5 watt maka baterai yang dibutuhkan dengan perhitungan.

$I=\frac{P}{V}$

$I=\frac{4 \mathrm{Watt}}{6 \mathrm{Volt}}$

$I=0.6 \mathrm{~A}$

$A h=I x h$

$A h=0.6 \times 4$

$A h=2.4 A h$

Maka kapasitas baterai yang dibutuhkan 2.4 Ah untuk menyalakan lampu selama 4 jam dengan lampu emergency 4 watt. Kapasitas baterai dapat disesuaikan sesuai kebutuhan.

\section{DAFTAR PUSTAKA}

[1] H. Asy'ari, A. Rozaq, and F. S. Putra, "Pemanfaatan solar cell dengan pln sebagai sumber energi listrik rumah tinggal,” 2014.

[2] J. M. Junior, R. S. F. Junior, J. P. C. da Costa, M. A. Marinho, R. A. Shayani, and R. T. de Sousa Junior, "Energy harvesting photovoltaic system to charge a cell phone in indoor environments," in 2014 International Conference on Composite Materials \& Renewable Energy Applications (ICCMREA), 2014, pp. 1-6.

[3] R. A. Nugroho, M. Facta, and Y. Yuningtyastuti, "Memaksimalkan Daya Keluaran Sel Surya Dengan Menggunakan 
RESISTOR (Elektronika Kendali Telekomunikasi Tenaga Listrik Komputer) Vol. 3 No. 2 e-ISSN : 2621-9700, p-ISSN : 2654-2684

Cermin Pemantul Sinar Matahari (Reflector)," Transient: Jurnal Ilmiah Teknik Elektro, vol. 3, no. 3, pp. 408-414, 2014.

[4] Y. Li, N. J. Grabham, S. P. Beeby, and M. J. Tudor, "The effect of the type of illumination on the energy harvesting performance of solar cells,” Solar Energy, vol. 111, pp. 21-29, 2015.

[5] A. Asrul, R. K. Demak, and R. Hatib, "Komparasi Energi Surya Dengan Lampu Halogen Terhadap Efisiensi Modul Photovoltaic Tipe Multicrystalline,” Jurnal Mekanikal, vol. 7, no. 1, 2016.

[6] R. Magrissa, "Pengaruh Intensitas Cahaya terhadap Efisiensi Sel Solar pada MonoCrystalline Silikon Sel Solar. Abstract - PDF Free Download,” adoc.tips. https:/adoc.tips/pengaruh-intensitas-cahayaterhadap-efisiensi-sel-solar-pada.html (accessed Jul. 30, 2020).

[7] "Energy Harvesting, tekhnologi harvesting," dokumen.tips. https://dokumen.tips/documents/energyharvesting-tekhnologi-harvesting.html (accessed Jul. 30, 2020).

[8] P. Van Harten and E. Setiawan, Instalasi listrik arus kuat. Binacipta, 1981.

[9] "Sistem dan Standar Pencahayaan Ruang | Kesehatan Lingkungan.” https:/putraprabu.wordpress.com/2009/01/06/ sistem-dan-standar-pencahayaan-ruang/ (accessed Jul. 30, 2020). 
RESISTOR (Elektronika Kendali Telekomunikasi Tenaga Listrik Komputer) Vol. 3 No. 2 e-ISSN : 2621-9700, p-ISSN : 2654-2684 